\title{
A Probe into the Development of Innovation Culture of Technology-Based Small and Micro-Sized Enterprises in the New Era
}

\author{
Na Wang* \\ Liaoning Shihua University, Northeastern University \\ School of Mining Engineering, School of Marxism \\ Fushun, China; shenyang, China
}

\author{
Jia Zeng \\ Liaoning Shihua University \\ League Committee \\ Fushun, China
}

\author{
Yuting Shao \\ Liaoning Shihua University \\ Student \\ Fushun China
}

\begin{abstract}
In order to promote the stable, healthy and rapid development of small and micro-sized technology-based enterprises in the new era, it is very important to explore the internal logic of their innovative culture development. Based on the theory of innovation and cultural evolution, this paper conducts a profound research and analysis from three stages, including the stage of advocacy, the stage of standardization and the stage of normalization. It innovatively put forward the concrete policy for the construction of the innovation culture development of the small and micro-sized technology-based enterprises, that is, using the theory of cultural evolution to study the development of innovative culture; in order to develop the culture of survival, innovation spirit and science and technology culture and promote the development of innovation culture; recognizing the important role of product culture, environmental culture and business culture in the culture of innovation to enhance the competitive advantage of enterprises; Promoting scientific cultural choice in the innovation stage of science and technology micro enterprises.
\end{abstract}

Keywords-New Era; Scientific and Technological Small and Micro-Sized Enterprises; Innovative Culture; Development Progress

\section{INTRODUCTION}

General Secretary Xi Jinping pointed out in the report of the 19th National Congress of the CPC that innovation is the first driving force leading development and the strategic support for building a modern economic system. After the 19th National Congress of the CPC, innovation has once again become the focus of the society, and has become the main theme of the current economic transformation and social development in China. Small and medium-sized enterprises play an important part of the national economy. As an important group of small and medium-sized enterprises, technology-based small and micro-sized enterprises, with its strong innovation motivation and flexible management mechanism, are becoming a new force in the economic development, but also a vital force in the promotion of national independent innovation ability and the construction of innovation system. Whether in promoting the growth of national economy, solving social employment, or promoting the optimization of industrial structure, scientific and technological small and micro enterprises have played a more important role. Innovation is a path that must be chosen for technology-based small and micro-sized enterprises. Innovation culture has become the core competitiveness of successful enterprises. In the new era, scientific and technological small and micro-sized enterprises explore the innovation culture construction and the cultural growth and evolution, and discover the unique characteristics of their innovation culture, then to put forward corresponding policies helpful for the promotion of the construction and development of themselves.

\section{The CONNOTATION OF TEChNOLOGY-BASED SMALL AND MICRO-SIZED ENTERPRISES AND INNOVATION CULTURE IN THE NEW ERA}

The 19th CPC National Congress's report made clear the importance of innovation-driven development and stressed that in hope of speeding up the construction of an innovation-oriented country and building a national innovation system, the new concept of development should be built so that scientific and technological innovation should be combined with institutional innovation, management innovation, business model innovation; industry innovation and cultural innovation should be vigorously advocated so as to promote innovation development in the whole society; and the whole society should bemobilized to actively participate in the times of reform and innovation. In the report of the 18th National Congress of the Communist Party of China in 2012, Hu Jintao pointed out to improve the core competitiveness of large and medium-sized enterprises and support the development of small and micro-sized enterprises, especially those based on science and technology. It can be seen that the development

2017 Liaoning Provincial Education Department's basic scientific research project "Research on the Construction of Innovative Culture of Technology-Based Small and Micro-Sized Enterprises" (L2017WQN008) 
and innovative culture of the scientific and technological small and micro-sized enterprises are encouraged and proposed to promote the economic transformation and to form an internal unity with the transformation of economic development mode, the realization of supply-side structural reform and the building of intellectual property power.

\section{A. Connotation and Characteristics of Technology-Based Small and Micro-Sized Enterprises in the New Era}

Scientific and technological small and micro-sized enterprises are intelligent intensive enterprises engaged in high-tech research and development, high-tech products production and management, independent accounting or relatively independent accounting. Which have both the ability of scientific research and development of high and new technology as well the production and management ability of high and new technology products. They are the important force in the development of high and new technology industries, the "incubators" for the transfer of high and new technologies to form large and medium-sized enterprises or enterprise groups, the bases for training a large number of talents in high-tech industries, the foundation of the development of high-tech industry and the management cell of high-tech development zone. Such small and micro-sized enterprises have common characteristics of small scale and relatively small investment, high-quality and young personnel, and high sensitivity market with strong timeliness [1]. As the most active group in scientific and technological innovation and have the most potential for economic development, scientific and technological small and micro-sized enterprises are the first explorers and practitioners in the market economy. Enterprises from the establishment, always adhere to the concept of close integration of production and science \& technology, as well that development and innovation move forward together [2].

\section{B. The New Connotation of the Innovative Culture given by Novel Genes in the New Era}

The study of innovation culture is originated from economics and developed on the basis of Schumpeter's theory of innovation. In 1912, Schumpeter first proposed the theory of innovation in the Theory of Economic Development where the common evolution of technology, organization and system were focused on, which is summarized as five innovations: product innovation, technological innovation, market innovation, resource allocation innovation, and organizational innovation by the descendants. Later Schumpeter not only thought that technological innovation belongs to the endogenous variable of economic development but also emphasized the decisive role of enterprises in the process of technological innovation and capitalist economic development [3].

At present, we have entered a new era of the development of socialism with Chinese characteristics. The most important thing for enhancing the ability of independent innovation in face of the future is to unswervingly follow the road of independent innovation with Chinese characteristics, adhere to the principles of independent innovation, keeping consideration focused on long-project, supporting development and leading the future, accelerate the pace of building an innovative country, plan and promote innovation from a global perspective, improve the original innovation, integrated innovation, and the ability to introduce and absorb to re-innovate, pay more attention to collaborative innovation, and do a good job in the top-level design of the strategic planning of science and technology thus to strive to stand out in the new round of scientific and technological revolution and industrial transformation. It is necessary to provide correct value guidance for scientific and technological innovation by cultivating scientific and technological ethics and advocating positive innovation culture. The connotation of the innovation culture is to carry forward the scientific spirit of truthful and practical, brave in innovation, pursuit of excellence, solidarity and cooperation, and selfless dedication, forming the value orientation of encouraging creation and pursuing excellence in the whole society to make innovation promotion an important connotation of national spirit.

\section{The CONSTRUCTION AND DEVELOPMENT OF}

INNOVATION CULTURE OF TECHNOLOGY-BASED SMALL AND MICRO-SIZED ENTERPRISES IN THE NEW ERA

The development of scientific and technological small and micro-sized enterprises in China is worrying. According to the statistical data, the average survival time of small and micro-sized enterprises in China is less than 3 years. Nevertheless, some small and micro-sized enterprises based on science and technology are still developing at an amazing speed, and some of which have even developed into famous large enterprises. Scientific and technological small and micro-sized enterprises of different types show significant differences and presents different characteristics in each stage. Therefore, what is the key factor to affect the construction and development of technology-based small and micro-sized enterprises influences not only the healthy and sustainable development of science and technology-based small and micro-sized enterprises themselves but also the construction process of an innovative nation. To revitalize the small and micro-sized enterprises of science and technology, it is necessary to start with hard power, at the same time, to strengthen the construction of "soft power", and to establish a cultural system with distinctive characteristics of the times and rich in the connotation of modern civilization value. Therefore, it is particularly essential to systematically study the construction and evolution of the innovation culture of small and micro-sized enterprises of science and technology.

\section{A. Innovative Cultural Genes in the Advocacy Stage of Small and Micro-Sized Enterprises Based on Science and Technology}

In the early stage of the development of technology-based small and micro-sized enterprises, scientific and technological personnel or institutions conduct studies on production feasibility, technical difficulties removal and intermediate experiments on selected scientific and technological achievements with commercial development prospects in order to transform them into real productivity thus producing new products (services) or new processes that can be marketed. The scientific research team of the enterprise is growing gradually. Each employee takes the different culture gene into the enterprise, which plays an important role in the formation of 
the enterprise culture. The different cultural genes conflict, collide and bring forth the new from the old. The innovation culture in science and technology-based small and micro-sized enterprises is a relatively stable habit of thinking and code of conduct gradually precipitated in the long-term development of the culture of equality, adventure spirit, innovation and change, skepticism and the spirit of individuality, openness, cooperation, etc. conducive to the stability, development and growth of the enterprise. People may find it difficult to find all its root causes and see its direct consequences at once, but it has a profound and permeable impact on all aspects and corners of the enterprise, having become an innovative cultural gene in the advocacy stage.

\section{B. The Cultivation of Innovative Culture in the Standardization Stage of Small and Micro-sized Enterprises Based on Science and Technology}

Through the early stage of entrepreneurship, science and technology-based small and micro-sized enterprises have achieved the transformation of scientific research results into real productivity, entering the stage of growth and development, in which enterprises mainly take expanding market share as the strategic goal, to initially form core competitive ability; the employees and core projects of enterprises tend to stabilize; and the enterprise culture is gradually standardized towards excellent innovation culture. Enterprise innovation culture developed and promoted by the enterprise from the three aspects of the material culture, the system culture and the concept culture should be toward the good and upward in its basic connotation and is the powerful and valuable weapon which guarantees the science and technology innovation to serve the employees' benefits and the enterprises' progress.

\section{Cultural Choice and Cultural Construction in the Normalized Stage of Science and Technology-Based Small and Micro-Sized Enterprises}

After a period of growth and the development of innovation culture, the growth rate of sales or profits of small and micro-sized enterprises of a technological type will stabilize and enter a normal stage after reaching a certain point. Science and technology small and micro-sized enterprises in the mature period have reached a certain scale, with relatively mature conditions in all aspects. However, with the gradual loss of the original technology advantage, its development speed began to slow down. Therefore, it is necessary to strengthen the research and development of high-tech products (services) or technology in order to grasp new technological advantages. At this stage, science and technology-based small and micro-sized enterprises become more perfect in management system, more rational in staffing, and richer in innovation culture, forming a relatively stable organizational structure. However, due to the involvement of more competitors, the competition is extremely fierce; so that the enterprise will adopt aggressive market strategy in order to concentrate all the strength and increase its development space, where the choice of innovation culture is more necessary and the construction of innovation culture is more urgent.
IV. POLICIES FOR PROMOTION OF THE DEVELOPMENT OF INNOVATION CULTURE OF SCIENCE AND TECHNOLOGY-BASED

\section{SMALL AND MICRO-SIZED ENTERPRISES IN THE NEW ERA}

Under the background of the new era, the research and exploration of the innovation culture of small and micro-sized enterprises of science and technology type have important practical significance for the development of science \& technology, economy, and society, and the realization of the innovation-driven strategy in our country, as well as play an important role in the development and steady growth of science and technology-based small and micro-sized enterprises. Science and technology enterprises, especially small and micro-sized enterprises with a large proportion, need to create a culture of innovation with the help of the innovative thinking and the creative technology and methods to solve those practical problems. Scientific and effective policies to promote the innovation culture in scientific and technological small and micro-sized enterprises will help the promotion of the overall scientific and technological innovation ability of our country.

\section{A. Using the Theory of Cultural Evolution to Study the Development of Innovative culture}

The theory of cultural evolution, a theory about the evolution of human culture formed on the basis of Darwinian biological evolution in the 19th century, whose basic core contents are the theory of human psychological consensus, gradual evolution, natural selection, survival of the fittest, etc. It is still a dynamic cultural theory that has an influence and continues to develop until now. Darwin, a British scientist, published his book the Origin of Species in 1859, in which "Once an individual of any kind of animal or plant mutates, as long as this mutation can in some way contribute to the competition for its survival, it will enable the individual to gain a competitive advantage over his peers." was proposed to indicate that all biological organisms and even all cultural forms have considerable plasticity and potential for change, and can be modified and constructed to a certain extent. Taking Darwin's theory of natural selection as a reference, Spencer explains his view of human development: The process of natural selection will lead to the strongest, most advanced, and the most suitable culture to become the most superior culture, to which other cultures will evolve [4]. The innovative culture of small and micro-sized enterprises based on science and technology has great flexibility and plasticity and has the potential for improvement. We should continue to develop the genetic advantages of good integration and constant innovation of the technology-based small and micro-sized enterprises. On the basis of the progressive culture evolution and the maintenance of the characteristics and connotations in the early cultural genes, the enterprises should be remolded and moderately adjusted, revised and evolve to gain competitive advantages in face of the new fierce competitive environment. 


\section{B. Moulding the Culture of Survival, Innovation Spirit and Science and Technology Culture and Promoting the Development of Innovation Culture}

In the Evolution of Culture, White expressed his understanding of culture that "There is a growing recognition that culture is a continuum, a process of events, a vertical transmission of one era to another, and transmigration horizontally from one race or region to another," he said."[4] Both evolutionary views and the role of communication in cultural development are contained in it. In the initial stage of science and technology-based small and micro-sized enterprises, employees gradually integrate their own survival culture, innovation spirit in order to reflect personal value and technology culture for the purpose of improving their professional skills into enterprises so as to earn a living. In this sense, strengthening the construction of scientific and technological ethics constitutes an important part of the construction of innovative culture. The ethics of science and technology refer to the thought and behavior criterion of the relationship between man and society, man and nature and man and man in the activities of scientific and technological innovation, which indicate the values, social responsibilities and norms of conduct that scientific and technological workers and their communities should abide by. Without the standard of science and technology ethics, the free development of science and technology innovation will inevitably lead to the harm to the human society caused by science and technology. Therefore, it is necessary to foster scientific and technological ethics and advocate positive innovative culture and spirit, thus to provide correct and standardized value guidance for scientific and technological innovation.

C. Recognizing the Important Role of Product Culture, Environmental Culture and Business Culture in the Culture of Innovation to Enhance the Competitive Advantage of Enterprises

The formation of innovative culture will be influenced by product culture, cultural environment, geographical environment, resource environment, social environment, commercial culture and national culture. Therefore, the enterprise culture in the advocacy stage is the main source and important blueprint of the formation of enterprise innovation culture. The dissemination of product culture needs a certain carrier, so that what we come into contact with in the cultural world is not information but the effect of information. The recipients of the spread of product culture react psychologically and physically to information as if the car we see on the street is not its design drawings and instructions but a tangible car; When using a phone, we know the battery time of the phone and the performance of its application, instead of the working principle of the battery and the program. Environmental factors are also extremely important in the development of innovative culture. As the discipline evolves, experts become more immersed in their own field, and a dominant orthodoxy which is difficult to be challenged may emerge. If a universal paradigm or technology becomes sufficiently advantageous, innovation needs to be cultivated in an isolated population before it can challenge the mainstream. With the rapid development of information technology and new media technology, business culture has gradually become the focus of entrepreneurial culture construction. Whether innovation can be accepted by the society depends on the degree of recognition of product culture, environmental culture and commercial culture.

\section{Promoting Scientific Cultural Choice in the Innovation Stage of Science and Technology Micro Enterprises}

Facing the fierce competition in the innovation stage, the technology-based small and micro-sized enterprises should vigorously advocate the scientific spirit of truthful and pragmatic, innovative, pursuit of excellence, unity and cooperation, and selfless dedication. The value orientation of encouraging creation and pursuing excellence should be formed within the enterprises, and technological innovation should be promoted to improve competitive advantages. Contention of various thoughts and respect for the academic culture of the scientists with individual characters should be encouraged to strengthen the innovation self-confidence; The exploration value of scientific research trial and error should be concentrated on to establish a fault-tolerant and error-correcting mechanism that encourages innovation and tolerates failure; A relaxed scientific research atmosphere should be created to protect the academic freedom of scientific and technological personnel. Innovative thinking is a special high-level thinking activity and spiritual process for human beings. Without innovative thinking, all human innovation activities, the development and progress of human civilization cannot be discussed. The cultural choice and cultural construction in the normal stage should be achieved through vigorous promotion of the scientific spirit of seeking truth and full cultivation of innovative thinking, to further provide intellectual support for the innovation of technology-based small and micro-sized enterprises.

\section{CONCLUSION}

In order to fully review the innovative culture of the enterprise, this paper is based on the perspective of small microenterprises in science and technology in the background of the new era, based on the theory of innovation and culture theory as the main theoretical background, and to research the development approach and law of the innovation culture of the small micro-enterprises in technology.

Research found: (1) The innovation culture construction of scientific and technological small and micro enterprises is a process of cultural evolution. Its culture has great flexibility and plasticity, and the potential of improving. Facing fierce competition in the new, it needs to reinvent itself, adjust itself, modify itself and evolve itself to gain competitive advantage; (2) The cultural genes of small and technological enterprises decide whether it has the development potential. The cultural gene in its initial stage is very important. It is the foundation and root of the development of innovation culture, and determines the lifeline of its development. (3) The survival culture innovation spirit and the science and technology culture constitute the science and technology small micro enterprise innovation culture gene. We advocate the innovation culture and spirit of innovation, and provide the correct standard value guidance for scientific and technological innovation by cultivating scientific and technological ethics. (4) The establishment of product culture, environmental culture and 
commercial culture is the science and technology development small and micro businesses during the construction of innovation culture, innovation can be accepted by the public, depend on the degree of recognition of product culture, environmental culture and commercial culture; cultural construction of science and technology innovation stage Small and micro businesses need to deal with the cultural choice. Cultural choice and cultural construction is to vigorously foster the scientific spirit of truthfully and foster innovative thinking, so as to provide intellectual support for the innovation of technological small and micro businesses.

\section{REFERENCES}

[1] Qin Yao. How Commercial Banks Support the Development of Science and Technology-Based Small and Micro-Sized Enterprises [J]. Modern Finance, 2012(3): 40-41.(In Chinese)

[2] Ling Bu, Heng Xiong, and Zhou Xing. Fifteen Theories of Cultural Anthropology [J].1988. (In Chinese)

[3] Wyatt. The Science of Culture [M]. Trans. Shen Yuan. Jinan: Shandong People's Press. 1988. Preface 2. (In Chinese)

[4] Wang Dan. Research on the Growth of Micro Innovation and Science and Technology-Based Small and Micro-Sized Enterprises [J]. Journal of Changsha University, 2015(6). (In Chinese)

[5] Lu Yuduo, Zhang Yanyan, Mao Jian, et al. Research on the Development Environment and Policy Support System of Science and Technology-Based Small and Micro-Sized Enterprises [J]. Science and Technology Progress and Policy, 2013, 30(18). (In Chinese)

[6] Ren Fengtian. A Review of Spencer's Social Evolutionism [J]. Journal of Chongqing University of Science and Technology (Social Science Edition, 2010(9). (In Chinese)

[7] Chen Yang. Cultural Evolutionism and Historical Materialism: From a Perspective of Progress [J].Academic Exchange, 2014(4). (In Chinese)

[8] Marvin Harris. Cultural Materialism. The Struggle for a Science of Culture [M]. New York: Rondom house, 1979. 